\title{
Identity Through Culture and Arts Education
}

\author{
Supyan Hussin* \\ University Kebangsaan Malaysia \\ supyan@ukm.edu.my
}

\begin{abstract}
Formal education may continually provide examples of social acts and cultural practices that embed the identity in the young learners at schools. Cultural and traditional identity is important in any community as it reflects the social values and social norms of the respective society. In a broader scale, the national identity development in any country is often planned through education to shape the identity of the nation. Using Malay cultural identity, this article questions how, what, and which identity could be constructed through culture and arts education learnt at schools. It argues that the identity has to be based on a framework that takes into consideration seven elements: philosophy (including region), (2) history, (3) belief systems, (4) thought, (5) emotion, (6) cultural behaviors and (7) lifestyle. Of these seven elements, there a number of values can be derived from and embedded in the teaching and learning activities in schools.
\end{abstract}

Keywords-formal education, culture, arts education, Malay identity framework

\section{INTRODUCTION}

Education in schools is always the best platform to introduce and embed cultural identity through formal curriculum. The identity can be easily seen in tangible forms such as dresses and costumes, social acts, foods, cultural practices, and way of life in local context. In the old days, when there were no schools where teachers could teach and guide young kids on social norms and good manners in addition to what has been taught by parents at home, public theatres or arenas were common places to convey the cultural messages to the public. When sketches, dramas, role plays, and other performing arts were presented on the stage, certainly cultural identity would be manifested through costumes, foods, manners, and social acts. The audience attending the shows might learn and acquire some of the cultural practices and values. They might imitate some of the behaviours of the actors and actresses performed on stage. This informal way of "education" might be not be able to provide ample examples of social acts and cultural practices that may reflect the identity of the local people in the community. On the other hand, formal education may continually provide numerous examples of social acts and cultural practices that embed the identity in the young kids who attend the formal schools.

Cultural or local identity is crucial in any community as it reflects the social values and social norms of the local community. It may also reflect the mind-set of the local people in the community. In a larger scale, the development of national identity of the local people in any country has to be planned well, and education is the best avenue to shape the identity of the nation. A conceptual framework of identity like Pancasila ${ }^{1}$ in Indonesia and Rukun Negara ${ }^{2}$ in Malaysia can be a reference center for the development of national identity through formal curriculum including culture and arts education. Still, Pancasila and Rukun Negara must be based on local wisdom that takes into consideration several aspects such politics, economy, history, sociology, psychology, philosophy, and belief systems. However, is Pancasila alone is adequate to develop local and national identity of Indonesia? Is Rukun Negara alone enough to develop the national identity in Malaysia? Would all citizens be considered equal? Would host community (indigenous people) and migrants or immigrants be considered the same in terms of power sharing, property ownership, and economic power? Would these countries adopt a "salad bowl" concept of identity or a "melting pot" concept when they develop the identity through culture and arts education?

\section{DEFINITION AND SCOPE OF "MALAY"}

The term "Melayu" can be controversial and confusing to some people. Some look at the "malay" as an ethnic group in Sumatera and in Malaysia. Others consider Malay as a "nation" or an umbrella (or "Rumpun") to many ethnics and sub-ethnics in Sunda continent or Sunda Plateau. We can debate on what is Malay using Shamsul Amri's approach in defining the identityterm: firstly, we can use "authority defined" approach to define what Malay is or we can adopt "everyday-defined" approach (Baharuddin, S. A., 2001). While the first one is defined by an authoritative body like a dictionary or legal documents such as country's constitution, the second one is defined by people everyday regardless of space and time. Nevertheless, for the sake of discussion, we would use an "authority-defined" approach to deal with the term "Malay". Alfred Wallace once introduced the term "Malay Archipelago" (Wallace, Alfred Russel, 1855) which consists of islands and peninsular in Sunda Plateau. Wallace studied the flora and fauna species In South East Asia and found unique characteristics of the species, and later introduced a line to split the region of the species: IndoMalayan Division and Austro-Malayan Division. Wallace shared his data and findings with Charles Darwin who later

\footnotetext{
${ }^{1}$ Pancasila is the national core ideology of the Indonesian government consisting of belief in God, Indonesian nationalism, humanitarianism or just and civilized humanity, democracy, and social justice.

${ }^{2}$ Rukun Negara is the national principles of Malaysia: Belief in God, Loyalty to King and Country, Supremacy of Constitution, Rule of Law, Good Behavior and Morality.
} 
used the data to develop his well-known theory, called evolution theory.

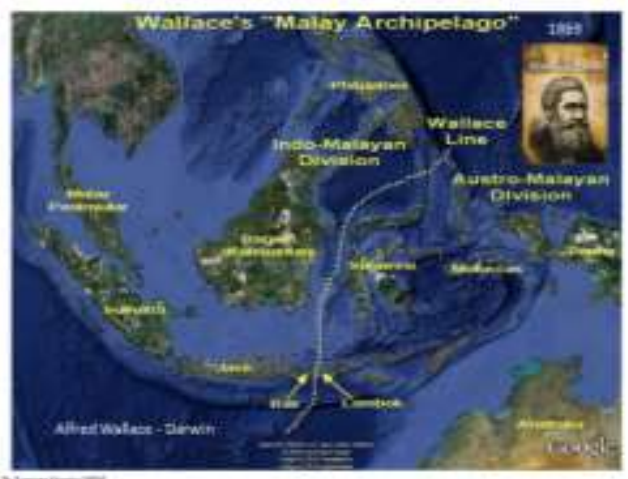

Figure 1: Alfred Wallace's Malay World and Wallace Line (Source:

https://yr9artassesmentecjohnwolseley.weebly.com/artwor ks.html)

Considered as a maritime region, consisting of the Malay Peninsula, now known as Malaysia, and Indonesian major islands like Sumatera, Jawa and parts of Borneo that are surrounded by many other small islands, the core group of the inhabitants is call "Malay nation" or "Rumpun Melayu". Within this nation, or the indigenous people of Sunda Plateau, it has more than 200 ethnic groups and subethnic groups scattered all over the Sunda Plateau. Nevertheless they share a lingua franca, namely Malay language as well as foods, cultural practices, cultural costumes, and cultural norms and practices. When people from the nearby regions, the Indian nation from India Plateau and Chinese nation from Yangtze Plateau migrated and/or travelled to Sunda Plateau for economic reasons like trading or political reasons, the "Malay nation" has no problem to accept, live and work together with the incoming nations. In fact, through a long socialization process among these three nations, the local people in Sunda Plateau had embraced some of the foreign elements from the Indian nation and the Chinese nation in their daily routines in terms of food, clothing, and social customs (Hussin, 2018). Although the migrants have assimilated themselves the local community over the years, their root of the ethnic group remains. The issue of identity may raise a conflict among the ethnics and/or sub-ethnics as to what are characteristics of identity that we should promote in culture and arts education in the? To answer this question, we need to have a working framework.

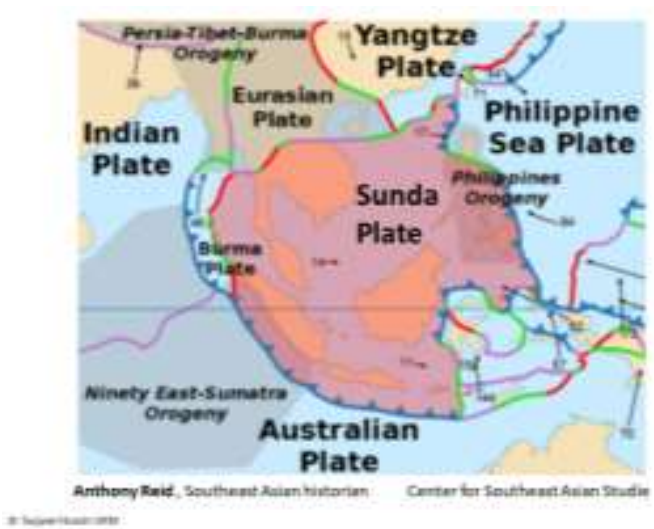

Figure 2: The Malay World on Sunda Plate (Source: https://en.wikipedia.org/wiki/Sunda Plate)

\section{III. “AKAL UDI MELAYU”@MALAY VALUES AND NORMS: A WORKING FRAMEWORK}

The "Malay nation", specifically focussing on Malay Archipelago, in Sunda Plataeu, has its own unique features. There is something special about the "Malay nation" that has been very open to the immigrants or other nations in the maritime region, without any major wars or blood spills. The Indian and the Chinese nations too perhaps could understand how to make themselves "feel like home" when they moved into the Malay Archipelago. They could live together peacefully and harmoniously for years without any major conflicts with the indigenous people or local host community. What makes the "Malay nation" unique is the concept known as "Akal Budi Melayu" or its closest translation, "Malay values and norms". This abstract concept is very complex that contributes to the socio-psychological makeup of the "Malay nation". This expression "Akal Budi Melayu" is made up of local knowledge and local wisdom that distinguish itself from other nation's local knowledge, like India and Chinese nations.

This Akal Budi Melayu@Malay Values and Norms is based on seven important elements: (1) philosophy (including region), (2) history, (3) belief systems, (4) thought, (5) emotion, (6) cultural behaviors and (7) lifestyle as illustrated n Figure 4. The seven elements are arranged in a pyramid shape that shows the bottom part of the pyramid is a strong foundation that supports all other elements above it in the framework. In the pyramid, each element affects and interacts with one another to form unique values and norms of the "Malay nation". The foundation of the Malay values and norms is the coexistence of the philosophy (including religion), belief system, and history of the Malay World. This is the most important basis of the Akal Budi Melayu@Malay Values and Norms in the illustrated in Figurae 4. No one should separate the three elements and must take these as a package. No one can ignore the three elements in nation and identity development because they highly influence other elements: the thought, cultural practices, and emotion. How "“Malay nation"” views the world and life, strongly interacting with flora and fauna as well as the tropical climate, its mind set is so unique that the "“"Malay nation"”. Beginning with paganism, the "“"Malay nation"” was known to have embraced Buddhism and Hinduism, and later Islam, being the most acceptable religion among the majority of the Malay in the Malay Archipelago. 


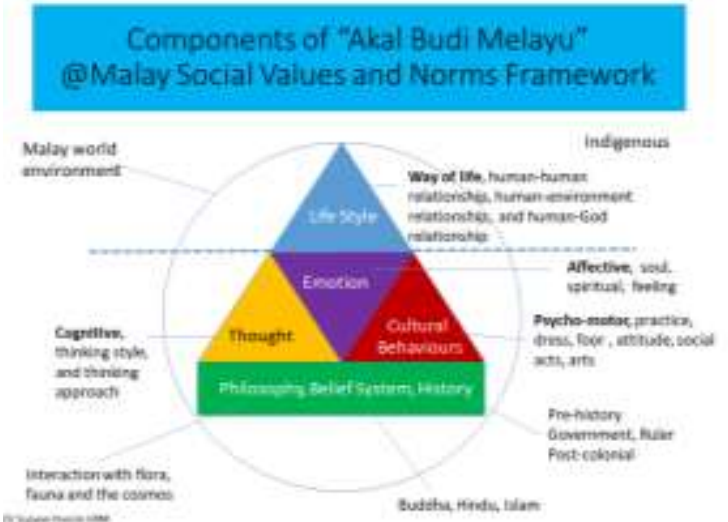

Figure 3: The Components of Akal Budi Melayu@Malay Values and Norms Framework

The Malay thought is highly influenced by the Malay philosophy (including religion) and history. The Malays have been governed by the monarchy system in the early kingdoms such as Sriwijaya, Majapahit, later Minangkabau, Pasai, Johor-Riau, and Melaka kingdom. It should be pointed out also that the Malay states in the northern Malay Archipelago were ruled by Malay Muslim rulers from Funan, Champa, and Patani even earlier than the existence of Melaka's Sultan Kingdom. With the presence of Islam, the Malays view life in this world as temporary and the life in the Hereafter is permanent. Therefore, the way they behave and live are shaped by the religious teachings. The local Malay cultural practices, foods, and dress codes are aligned to the teachings of Islam. The Malay thought, accompanied by Malay behaviour brings in a balance in the Malay emotion.

The term emotion, that is placed in the middle of the triangle, as illustrated, manifests how "“"Malay nation"” recognizes the four elements that make up its emotive aspect. The "“Malay nation"” is seen as family and group oriented, and less individualistic. Perhaps a relevant metaphor that represents this emotive aspect of the "Malay nation" is the banana plants. The nature of banana plants shows that the plants cannot live by itself without the banana seedlings growing closely around the main banana plants. This metaphor signifies how Malay people's pattern of life living with family members maintains a strong family kinship or group-based community. When the plants produce a bunch of bananas, the bunch will be harvested, and bananas are removed from the bunch in a cluster form so that it can be carried easily in light weight. Later, each banana will be removed from its cluster for consumption. In the Malay community, when "big life events" take place in the family kinship such as wedding, funeral, birthday celebration, birth of new born, and Hajj pilgrimage, the members in the Malay family and their inlaws will get together for a thanksgiving congregation. Conceptually, each banana that was removed or plucked away from the bunch "would return" (brought back) to its original bunch of banana when there is a major life event. This phenomenon manifests how close the intimate feeling of the members in the Malay family, and they will gather again for the "big events" conducted by the family members.
When integrating the six elements in the Akal Budi Melayu@Malay Values and Norms framework, one can see the outcome of it in the lifestyle of the "Malay nation". The Malay nation would reflect their thought, cultural behaviours, emotion and lifestyle that are governed by the philosophical and historical inputs in their lifestyle. Based on long historical records of the Malay world and civilization in Sunda Plateau, these are a few common values and norms that are vividly manifested in the lifestyle of the "Malay" community. These values may contribute to the making of the identity of the local people and identity of the citizen and nation of Indonesia and/or Malaysia:

1. Accommodative

2. Assimilative

3. Tolerate

4. Cooperative, work together

5. Group-oriented, family oriented

6. Adaptive

7. Flexible

8. Religious

9. Respect

10. Reserve

11. Negotiable

12. Moderate

13. Caring

14. Gentle

These are the values that can be inculcated in the teaching and learning activities in culture and arts education in the school. The curriculum and syllabus for culture and arts education may have activities that are already outlined in teacher's handbook. It is during the process of teaching and learning, teachers could ensure the local identity and national identity are developed in the lessosn and learning activities as time passes by.

To illustrate, given a Malay village or community, most Malay people practice moderation in their life. They may not show off openly of their extravagant and luxury items they have. They respect neighbours and care about their neighbours. They always cooperate and work together communally known as "gotong-royong" for the sake of family and the community like in wedding ceremony, funeral procession, and cleaning up projects in the community. If a non-Malay moves into the village, Malays usually would accommodate the person, and later adopt and assimilate some of the foreign elements in the Malay community especially the food (like chopstick, curry, maruku, biryani rice, tofu, black jelly, salted egg) and the dress (kurta, kungfu style dress, cheongsam, songkok). Their flexibility and adaptive features quickly bring the relationship closer to the new comers in the community, and thus, new comers feel like home. If the Malay people notice anything bad, the way they address the issue is carried out in diplomatic and polite ways. They usually tolerate and reserve their negative comments when it comes to dispute or disagreement, and would negotiate for better outcomes rather than engaging in direct confrontation. Consequently, all these values and norms lead to peaceful and harmonious relation in the family and the community as seen in the lifestyle of the Malay people. 
The following diagram shows an analogy of iceberg that manifests the visible lifestyle that is derived from values and norms based on the philosophy (including religion), thought, behaviour, and emotion that are literally invisible. The "lifestyle" or the manners how people live and behave would inform us the kind of thought, behaviour, and emotion of the "Malay nation".

Another good example in the lifestyle of the "Malay nation" is represented in Silat, the Malay martial arts or self-defence (Hussin, 2017). Unlike Kung Fu and Tea Kwan Do, in Silat, both sides of the fighters will make a lot of moves, known as bunga silat (literally the flowery movement) around each other before the engage in body contact physically. This bunga silat connotes the arts of negotiation, without using verbal language, and seek possible avoidance of physical contact of the body. Only when it is unavoidable, the fight, or to a higher degree of anger called amok, will take place aggressively. Nevertheless, during the fight, the Malay fighters will not lift up their foot above the opponent's head or kick the opponent's head. The Malay people believe the head, the top part of the body, is to be respected as it is where a rational mind resides.

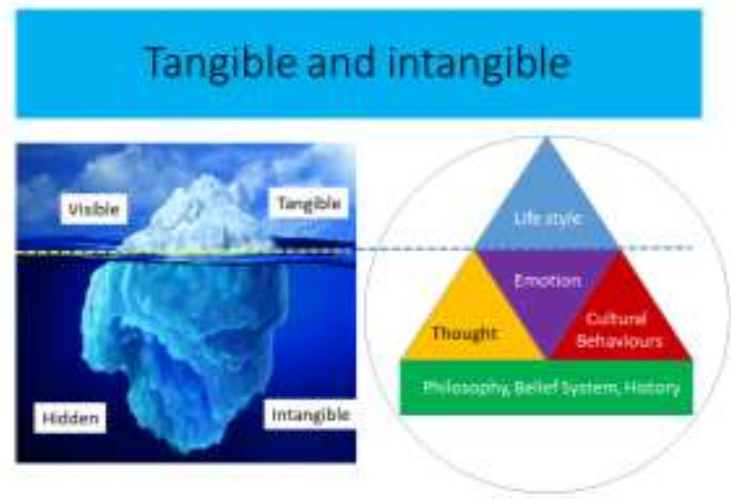

Figure 4: Iceberg metaphor and the Malay Values and Norms@AkalBudi Melayu Framework

Given the common scenarios of the social acts and cultural behaviours of the "Malay Nation", including how the local people treat the immigrants and foreigners as special guests. The "Malay Nation" tends to accommodate them, show good respect to them and provide helps where possible. Figure 4 shows the tangible lifestyle can be seen every day and everywhere in the "Malay nation" community but what really contribute to that life style are the intangible of invisible elements that cushion the "life style".

Another interesting aspect of Akal Budi Melayu@Malay Values and Norms framework is that it carries specific colours that signify some meanings. The green at the bottom of the triangle as a basis of the framework connotes fertile, fresh, and prosperity. It helps to influence and shape the Malay thought, cultural behaviours and emotion. The orange is the colour of the sun that always provides the best light and energy. The mind, where the thought is resided in, will guide the person to think rationally. The red colour signals blood that is always lively active, dynamic, vibrant, and productive. The purple represents the heart that is stable, sitting in the middle between the thought and behaviours, but all are cushioned by the philosophy, belief system and history of the past.

Unlike the western colonist from Europe or from Japan, the "Malay nation" has never colonized or attacked other nations in the world history. They also have never chased away immigrants from other continents or plateaus to live in this region of Sunda Plateau, the Malay Archipelago. In fact, they accommodate them, allow for assimilation of acceptable foreign cultural values and norms into its community, tolerate with differences, and live happily together. On the other hand, when colonists came to the Malay Archipelago, they conquered the land, controlled the region, and displaced the people in power. The "Malay nation" has never been seen doing such thing to other nation or country, but live together with the local people. For example, the Malay nation from Malay Archipelago, specifically the Bugis from Makassar, was the first nation reached Australia in $15^{\text {th }}$ century, followed by Dutch in $16^{\text {th }}$ century, and British in $17^{\text {th }}$ century (Yacob, 2017). The Malay nations did not conquer the land, control the region, and displaced the people in power in Australia, rather lived together with aborigines in Australia, assimilate with the local way of life, married the local people, and lived in that local community people peacefully and harmoniously.

\section{CONCLUSION}

The identity of nation or citizen or simply local people has to be developed and can be shaped in the people through culture and arts education. However, the identity has to be based on a framework that takes into consideration seven elements: philosophy (including region), (2) history, (3) belief systems, (4) thought, (5) emotion, (6) cultural behaviours and (7) lifestyle. Of these seven elements, there must values that be derived from, and can be embedded in the teaching and learning activities in schools. Akal Budi Melayu@The Malay values and norms are well-embedded in the lifestyle of the "Malay people" that make them warm and friendly as they accommodate and tolerate with different ethnic groups in the Malay Archipelago. Throughout the history of the world, the Malay nation has been dealing with the larger number of other nations such as Chinese, Indians, Portuguese, Dutch, Arab, English, and Japanese who came to this part of the world political, religious, economic and social reasons. The Malay nation has been very receptive to a larger extent, although small frictions among the nations in the region are unavoidable. Nevertheless, the Malay nation never destroyed and conquered the land of other nations, unlike western nations and Japanese. The Akal Budi Melayu@Malay Values and Norms could have been one of the important concepts that govern the Malay nation to appreciate and enjoy peace and harmony in the Malay Archipelago, the homeland of the Malay nation. 


\section{REFERENCES}

Baharuddin, S. A. (2001). A history of an identity, an identity of a history: The idea and practice of 'Malayness' in Malaysia reconsidered. Journal of Southeast Asian Studies, 32(3), 355366.

Wallace, Alfred Russel (1855). "On the Law which has regulated the introduction of species". Western Kentucky University. http://people.wku.edu/charles.smith/wallace/S020.htm October 2019].
Supyan Hussin. (2018). Malay values and norms in establishing peace and harmony in the community of the Sunda Plataeu. Paper presented at 1st International Conference on Local Wisdom (INCOLWIS) Yogyakarta, Indonesia, 9-10 August 2018

Supyan Hussin. 2017. Seni Silat Melayu satu perlambangan Akal Budi Melayu. Paper presented at Wacana Warisan Borneo. Universiti Malaysia Sabah. 20 Desember 2017.

Dr Teuku Chalidin Yacob. 2017. Muslim Melayu Penemu Australia. Jakarta: MINA Publishing House. 